\title{
Telocytes of the mammary gland stroma
}

\author{
N. Petre1, 2, M.C. Rusu1, 3, F. Pop ${ }^{4}$, A.M. Jianu ${ }^{5}$ \\ ${ }^{1}$ Division of Anatomy, Faculty of Dental Medicine, "Carol Davila" University of Medicine and Pharmacy, Bucharest, Romania \\ ${ }^{2}$ The "Prof. Dr. Dimitrie Gerota" Emergency Hospital, Bucharest, Romania \\ ${ }^{3}$ MEDCENTER — Centre of Excellence in Laboratory Medicine and Pathology, Bucharest, Romania \\ ${ }^{4}$ Division of Pathologic Anatomy, Faculty of Medicine, "Carol Davila" University of Medicine and Pharmacy, Bucharest, \\ Romania \\ ${ }^{5}$ Department of Anatomy, "Victor Babeş" University of Medicine and Pharmacy, Timişoara, Romania
}

[Received: 4 October 2015; Accepted: 21 October 2015]

\begin{abstract}
Although confusions persist in what concerns the terminologies used for describing the fibroblastoid cells of the stromal compartments, the expression of antigens in such cells gradually directs their diagnosis towards a stem/progenitor phenotype. The stromal cells with long, slender and moniliform prolongations were named "telocytes" (TCS), their cell processes being termed "telopodes". However, the mammary gland TCS were not evaluated for the CD34 expression. Thus an in vivo immunohistochemical study was designed; antibodies against CD10, CD34, CD117/c-kit and vimentin were applied on human mammary gland samples of 8 donor patients. Resident CD34-positive stromal cells positive for the TCS morphology were found building consistent stromal networks and ensheathing microvessels and excretory units. Such cells were CD10 \pm /c-kit-/vimentin+. According to the current concepts regarding the in vivo stem/progenitor cells the CD34+ TCs of the mammary stroma could be actors in the mammary stem niche and their antigens expression could relate to different stages of differentiation. (Folia Morphol 2016; 75, 2: 224-231)
\end{abstract}

Key words: CD34, telocytes, mesenchymal stromal cells, stem cells

\section{INTRODUCTION}

In 2005, light microscopic evidence was obtained of fibroblastoid stromal cells with long, thin and moniliform processes within the mammary gland (MG) stroma [30]; such cells were termed at that time interstitial Cajal-like cells (ICLCS). In 2010 the Romanian and Italian researchers renamed these cells from ICLCs to telocytes (TCs), their processes, long of "tens-up to hundreds of [micro]m", being named telopodes [31]. It was unequivocally stated that only transmission electron microscopy (TEM) "allows sure identification of telocytes, evaluation of the cell-tocell interrelationships, and a detailed description of the telopodes" [15]. This attitude was kept until 2014 when it was reinforced that "the features of telocytes are obvious only by transmission electron microscopy" [42]. In these regards, the initial identification of MG ICLCs in light microscopy [30], which keeps as the only in situ evidence of MG TCs in human tissue, could raise doubts. The only proofs of mammary telocyte-like cells resulted after an in vitro experiment of breast cancer reconstitution performed recently, in which TCs were identified in primary culture cells by phase contrast microscope [25], no specific marker being used then. Indeed, at this time a specific immune phenotype of TCs was not clearly established [34];

Address for correspondence: M.C. Rusu, MD, PhD, Dr.Hab., Prof., "Carol Davila” University of Medicine and Pharmacy, 8 Eroilor Sanitari Blvd., RO-76241, Bucharest, Romania, tel: +40722363705, e-mail: mugurel.rusu@umf.ro 
although the most used markers which point to TCs, but not exclusively, are CD34 and c-kit [15].

It was only recently indicated by the Italian researchers that "In the adulthood, TC may be considered mesenchymal stromal cells able to differentiate in different cell types, such as the interstitial cells of Cajal, the resident myofibroblasts and the fibroblasts" [43].

It was also repeatedly stated that TCs "nurse" stem cells (SCs) in the stem cell niches [15, 31, 32, 47]. However, CD34, as well as CD117/c-kit, are well known markers of cells with different levels of stemness [44]. Although CD34 was used for the in vitro study of MG TCs [25], that antibody was not applied for the in situ evidence of MG ICLCs [30], further renamed to TCs. Therefore, we aimed at studying by immunohistochemistry the in situ CD34 phenotype of the MG spindle-shaped stromal cells in normal human tissue.

\section{MATERIALS AND METHODS}

Human mammary gland samples were obtained after surgery from 8 female patients with ages varying from 46 to 52 years. Informed consent for research use of tissues was obtained prior to surgery. Approval for the present study was granted by the institutional (2nd affiliation, author \#1) Bioethics Committee. All experiments on human subjects were conducted in accordance with the Declaration of Helsinki (http://www.wma.net/en/30publications/10policies/ b3/index).

Mammary samples were fixed immediately after removal, kept for $24 \mathrm{~h}$ in buffered formalin (8\%), and then processed with an automatic histoprocessor (Diapath, Martinengo, BG, Italy) with paraffin embedding. Sections were cut manually at $3 \mu \mathrm{m}$, and were mounted on SuperFrost ${ }^{\circledR}$ electrostatic slides for immunohistochemistry (Thermo Scientific, Menzel-Gläser, Braunschweig, Germany).

The following anti-human primary antibodies were used: (a) anti-CD34 (clone QBEnd/10, Biocare Medical, Concord, CA, USA); (b) anti-CD10 (clone 56C6, Biocare Medical, Concord, CA, USA); (c) antiCD117/c-kit (clone Y145, Biocare Medical, Concord, CA, USA); (d) anti-vimentin (clone SP20, Biocare Medical, Concord, CA, USA).

For CD34 labelling, tissues were deparaffinised and hydrated, then endogenous peroxidase was blocked using Peroxidazed 1 (Biocare Medical, Concord, CA, USA). Carezyme I - Trypsin was used for enzyme digestion. Endogenous biotin was blocked and background blocker was applied to reduce non-specific background staining. The primary antibody was applied at a dilution of 1:100, at room temperature, for $60 \mathrm{~min}$. Then a two-step horseradish peroxidase (HRP) detection method using the 4plus detection system was applied, and a HRP-compatible chromogen diaminobenzidine (DAB) was applied. Sections were counterstained with haematoxylin and rinsed with deionised water. For washing steps was used tris-buffered saline (TBS) solution, pH 7.6.

For CD10 labelling, tissues were deparaffinised and rehydrated, then endogenous peroxidase was blocked using Peroxidased 1 (Biocare Medical, Concord, CA, USA). For the heat induced epitope retrieval was used the Decloaking Chamber (Biocare Medical, Concord, CA, USA) and retrieval solution pH 6 (Biocare Medical, Concord, CA, USA), the latter being a buffer specially formulated for superior $\mathrm{pH}$ stability at high temperatures. Background blocker (Biocare Medical, Concord, CA, USA) was used to reduce non-specific background staining. The primary antibody was applied at a dilution of 1:40. As detection system was used MACH 4 (Biocare Medical, Concord, CA, USA) which is a two-step (probe/polymer) universal HRP detection method. A HRP-compatible chromogen (DAB) was applied. Sections were counterstained with haematoxylin and rinsed with deionised water. For washing steps was used TBS solution, pH 7.6.

For CD117/c-kit labelling, tissues were deparaffinised and rehydrated, then endogenous peroxidase was blocked using Peroxidased 1 (Biocare Medical, Concord, CA, USA). For the heat induced epitope retrieval was used the Decloaking Chamber (Biocare Medical, Concord, CA, USA) and retrieval solution pH 6 (Biocare Medical, Concord, CA, USA). Background blocker (Biocare Medical, Concord, CA, USA) was used to reduce non-specific background staining. The primary antibody was applied at a dilution of 1:200. As detection system was used MACH 2 rabbit HRP polymer detection (Biocare Medical, Concord, CA, USA) which consists of a single reagent applied after the primary antibody. A HRP-compatible chromogen (DAB) was applied. Sections were counterstained with haematoxylin and rinsed with deionised water. For washing steps was used TBS solution, pH 7.6.

For vimentin labelling was used the same protocol as for $\mathrm{CD} 117 / \mathrm{c}-\mathrm{kit}$, the primary antibody being used at a dilution of 1:200. 


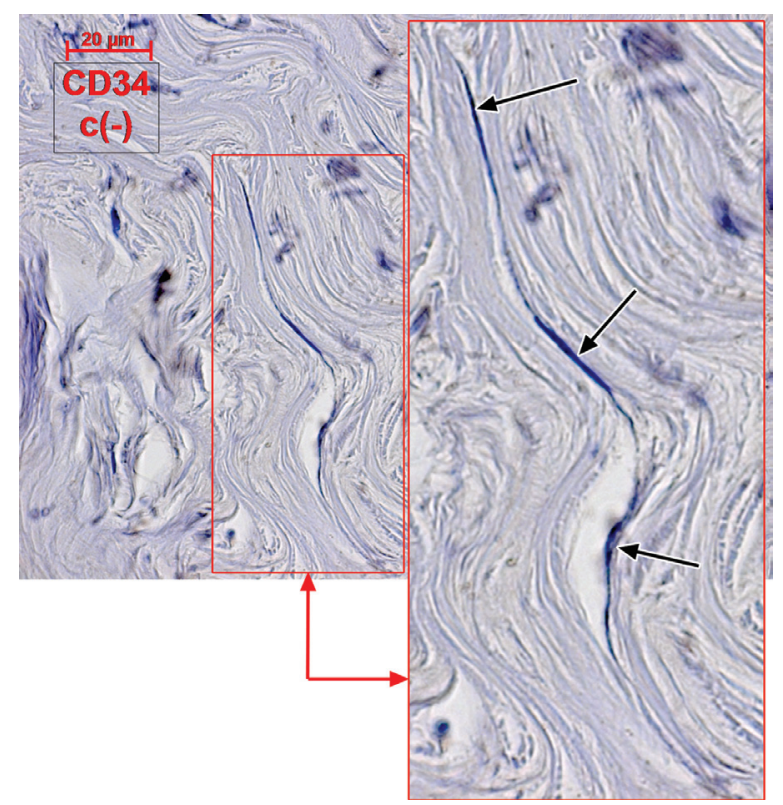

Figure 1. Internal negative control of CD34 labelling on normal mammary samples, haematoxylin-stained. Serially linked fibroblastoid stromal cells with long and moniliform prolongations are identified (inset, zoomed-in).

\section{RESULTS}

The normal structure of the mammary samples was evaluated on the haematoxylin and eosin-stained slides and on the haematoxylin-stained control slides (Figs. 1, 2). Terminal duct lobular units consisting of terminal ductules, intralobular collecting ducts and the intralobular stroma were separated by fibrous interlobular tissue built-up by densely packed collagen fibres and embedded cells of fibroblastoid shapes. The fibroblastoid cells of the MG stroma presented long and extremely long cell processes serially linking the cells along the collagen bundles (Fig. 1). Prolongations of the stromal cells were dichotomous (Fig. 2).

On CD34-labelled slides both the intralobular and interlobular stromal compartments were found rich in immune positive fibroblastoid cells (Figs. 3,4 ) with long (tens of micrometres) moniliform cell processes, which were building consistent networks. Being serially linked, these stromal CD34-positive cells ensured cellular paths of stromal transmission of hundreds of micrometres. Although such stromal cells were also neighbouring microvessels they were accurately distinguished of the CD34-positive vascular endothelial cells (Fig. 5). Moreover, the CD34-positive cells building stromal networks were projecting processes upon the perivascular ones (Fig. 5) thus integrating

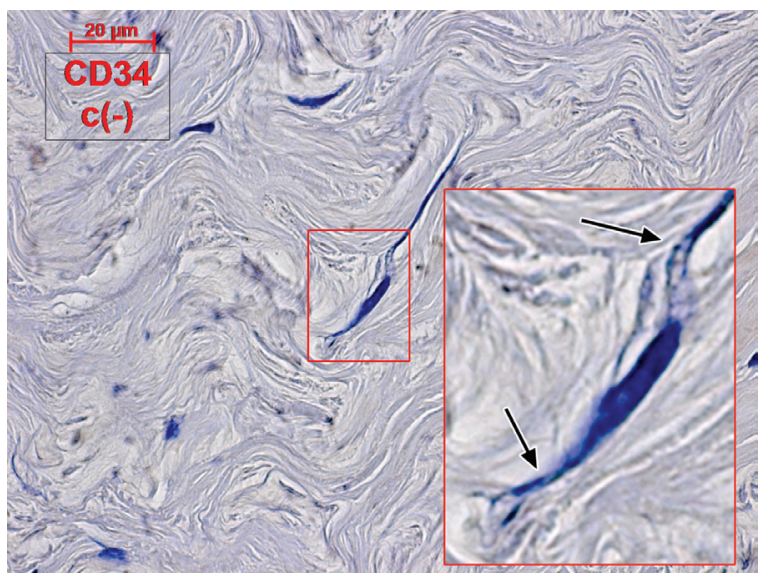

Figure 2. Internal negative control of CD34 labelling on normal mammary samples, haematoxylin-stained. The fibroblastoid cells of the interlobular stroma have dichotomous prolongations (arrows, zoomed-in inset).

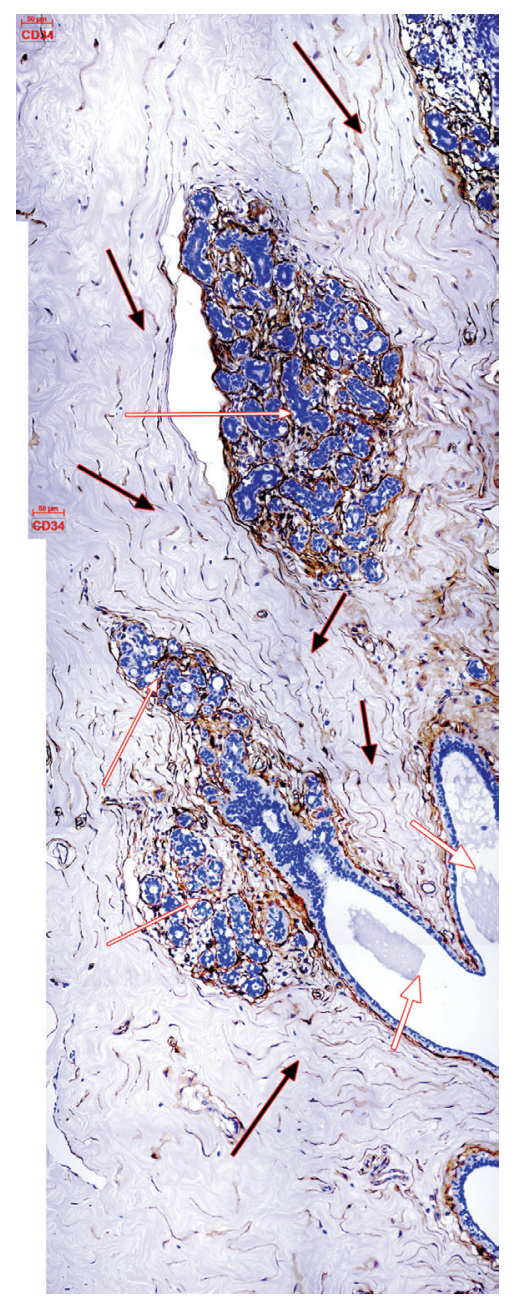

Figure 3. CD34 labelling of normal mammary samples. The thin white arrows indicate mammary excretory units, the thick white arrows indicate excretory ducts and the black arrows point to a consistent stromal network of CD34-positive fibroblastoid stromal cells. Digitally reconstructed image (9 micrographs). 


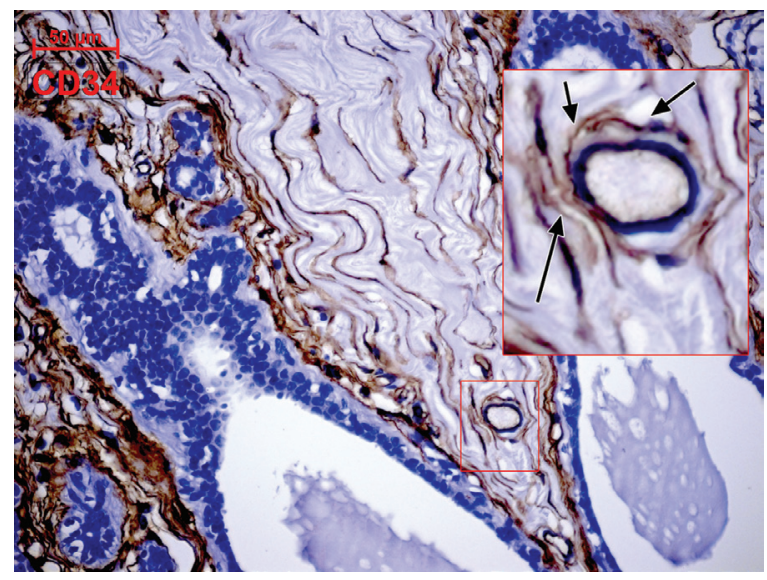

Figure 4. CD34 labelling of normal mammary samples. CD34-positive stromal fibroblastoid cells (arrows) are serially linked.

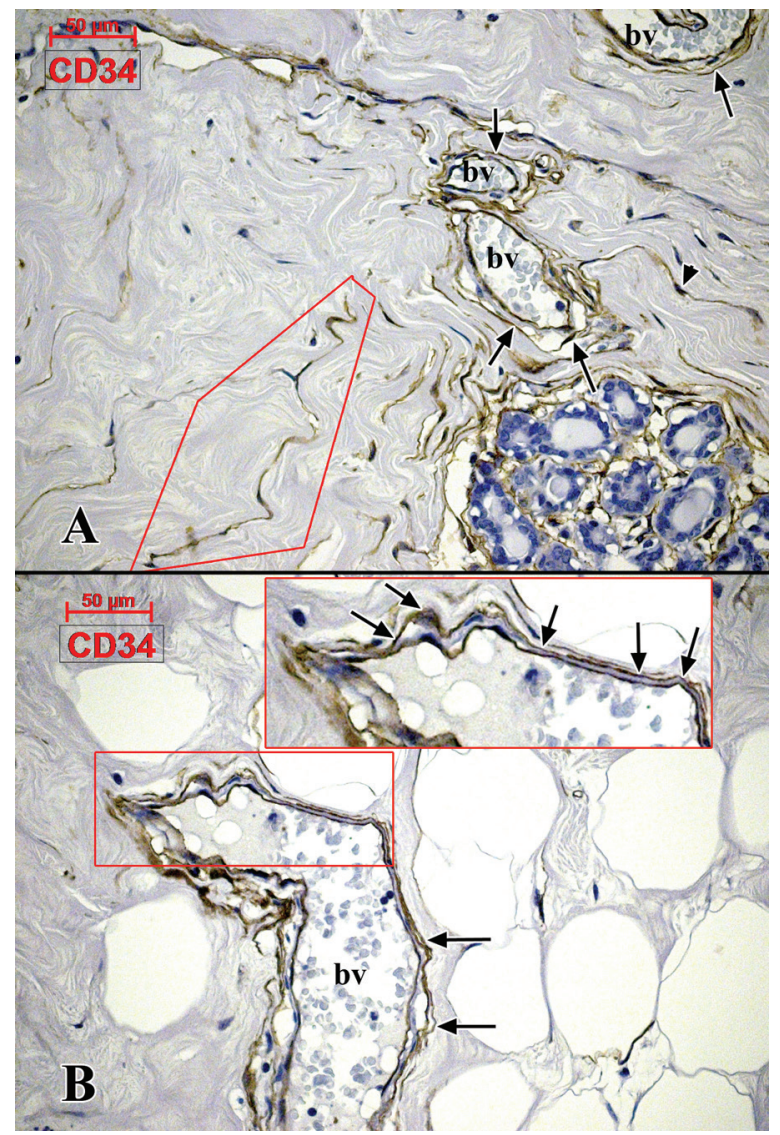

Figure 5. CD34 labelling of normal mammary samples. Perivascular CD34-positive spindle-shaped cells with long prolongations are indicated (arrows, A, B); similar cells are collagen-embedded, build networks in the perivascular stroma (polygonal shape, $\mathbf{A}$ ) and project prolongations (arrowhead, A) on the perivascular ones. The perivascular CD34-positive cells are distinctive of the CD34-positive vascular endothelial cells (zoomed-in inset, B).

these later into a general network. Around the excretory units the CD34-positive stromal cells were

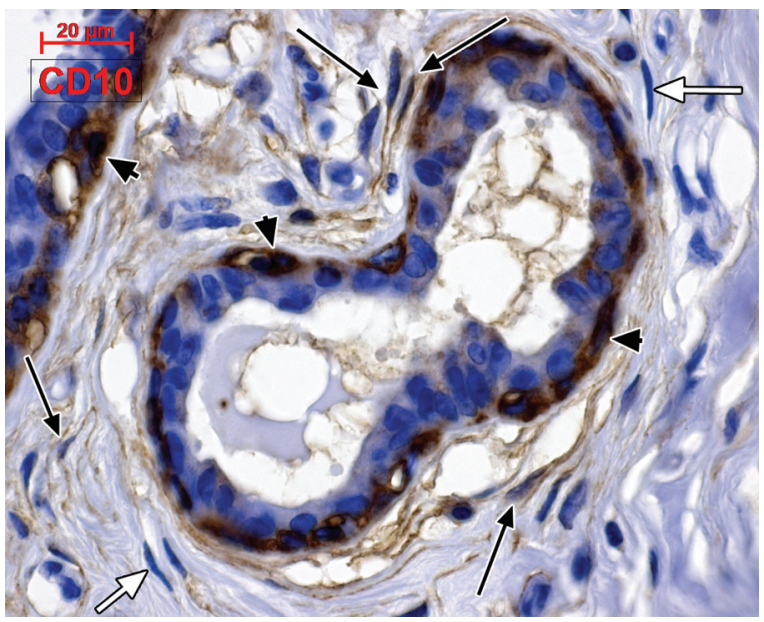

Figure 6. CD10 labelling of normal mammary samples. The ductal myoepithelial cells are CD10-positive (arrowheads). The intralobular stromal cells are either CD10-positive (black arrows), or CD10-negative (white arrows).

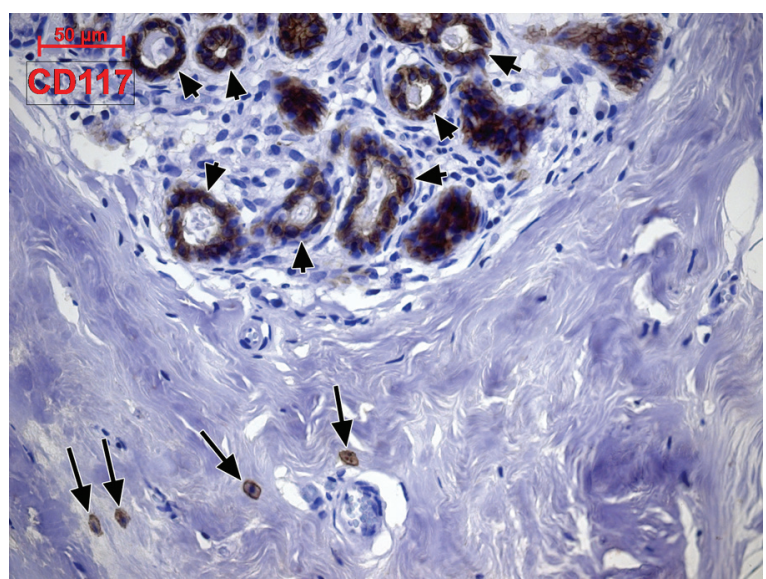

Figure 7. CD117/c-kit labelling of normal mammary samples. Epithelia of terminal ducts (arrowheads) and stromal mast cells (arrows) are the only positively labelled elements.

usually building multilayered sheaths. The intralobular CD34-positive cells displayed shorter prolongations and were building coverings, usually single-layered, around the ductules.

CD10 labelled the ductal myoepithelial cells and also a subset of inter- and intralobular fibroblastoid stromal cells; morphologically identical stromal cells were however CD10-negative (Fig. 6).

CD117/c-kit labelled the terminal ductules, the luminal cells of the ducts and stromal mast cells; other stromal cells were negative for this antibody (Fig. 7).

Vimentin labelled the myoepithelial cells of ducts and the microvascular endothelia; the stromal fibroblastoid cells labelling resulted positive (Fig. 8). 


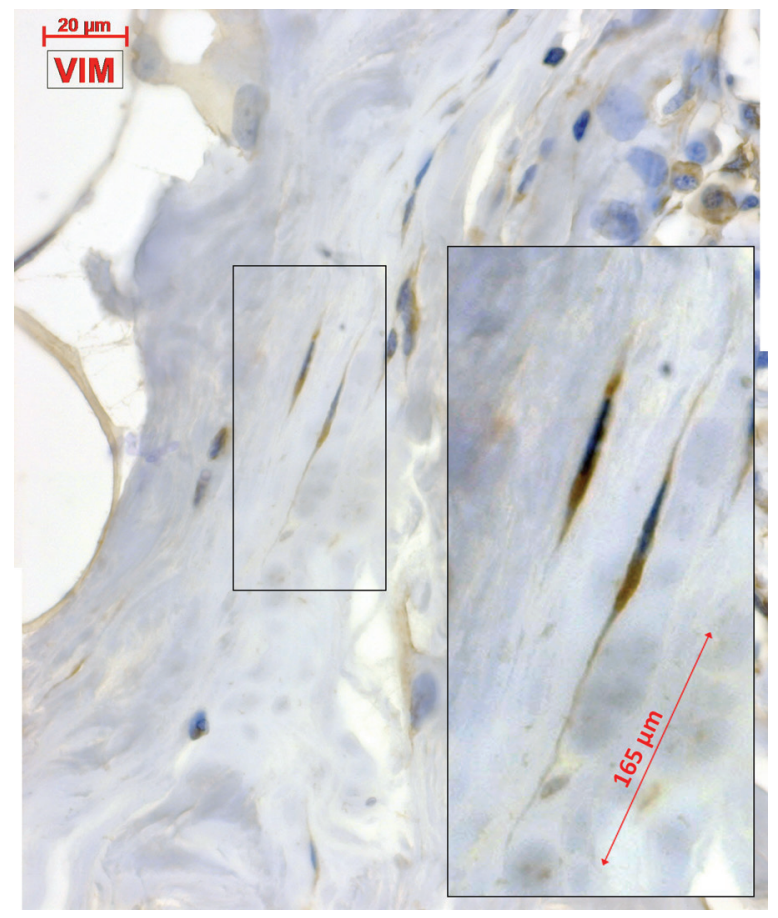

Figure 8. Vimentin labelling of normal mammary samples. Stromal fibroblastoid cells with long prolongations express vimentin. Inset: magnified detail.

\section{DISCUSSION}

A recent study [6] was focused upon CD34-positive "fibrocytes" of the MG stroma. It was evaluated there the stromal loss of CD34 expression and acquisition of smooth muscle actin phenotype as a condition for invasiveness of breast carcinoma. The authors document there a series of papers referring to the bone marrow-derived circulating fibrocytes firstly described by Bucala et al. [4], which are defined as acting in reparatory processes and presenting a combined, mesenchymal, haematopoietic and stromal phenotype (e.g.CD34+/CD45+/vimentin and/or collagen I, collagen III, alpha-smooth muscle actin) [36]. The authors distinguish the circulating fibrocytes of constitutional fibrocytes already present within the stromal compartment and available for phenotypic changes during the reparatory processes. The distinction between resident and circulating CD34-positive fibrocytes was clearly indicated by Diaz-Flores et al. [13], who brought convincing arguments when claiming that CD34-positive stromal fibroblastic/fibrocytic cells are, no matter the different names they were given by different research groups, a subset of stromal cells which "in addition to having the general functions of fibroblasts, behave as native mesenchymal stem cell progenitors (after losing CD34 expression), regulate the growth, maturation and differentiation of adjacent cells, and participate in immunomodulation". In their analysis, Diaz-Flores et al. (2014) [13] included not only the fibrocytes, but also the TCs, a stromal cell subtype only defined by a morphological pattern: "cells with telopodes" [3, 29], these later being long, slender and moniliform cell prolongations [37-39]. Unfortunately, although TCs are consistently investigated, and it was suggested that they could, as well, be either resident, or bone marrow-derived cells with that peculiar morphology [38], the existing studies did not yet take into account that instead of being "nurses" for the neighbouring stem cells (see also Introduction) TCs could be transit amplifying cells (TACs) deriving from neighbour stem cells, which would justify their positive CD34 and c-kit phenotypes. This is convergent with theories indicating that TCs behave as progenitor cells [11-13], thus TACs.

The mammary TCs were initially evaluated exclusively by means of light microscopy, with methylene blue and c-kit stains [30] and were viewed then as c-kit-positive ICLCs. They were not searched then for the CD34 expression. It was documented that, in human chorial villi, some TCs are CD34-positive, some are c-kit-positive [15, 41]. Here a CD34-positive but c-kit-negative phenotype was found. This reinforces the observation of Diaz-Flores et al. (2014) [13] that such stromal cells behave like stem/progenitor cells after losing the CD34 expression. In these regards, the CD34 and the CD117/c-kit phenotypes are reciprocally exclusive in stromal fibroblastoid cells.

Mesenchymal stem cells (MSCs) selectively proliferate to tumours and contribute to the formation of tumour-associated stroma [16]; bone marrow-derived MSCs cause the cancer cells, in human, to increase their metastatic potency [19]. Except MSCs, adult marrow also contains haematopoietic stem cells (HSCs) and endothelial progenitor cells [1]. To establish a MSC diagnosis, in vitro experiments are needed to evaluate the plastic-adherence of the colonies. Actually, the concept of MSCs is becoming increasingly obscure and the exact identity of MSCs in vivo is not yet clear $[21,24,35]$. On other hand, endothelial progenitor cells usually express c-kit and CD34, a phenotype which was also described for TCs (see Introduction) but was not discussed against a stem cell diagnosis. In this regard, the CD34-positive but CD117/c-kit negative phenotype we found 
in this study can indicate rejection of an endothelial tip cell diagnosis, HSCs being already rejected when the stromal compartment is observed. This reinforces a mesenchymal stem/progenitor phenotype of the stromal mammary fibroblastoid cells we studied, which is supported by recent experiments in which TCs were found positive for CD29 [3], a known MSCs marker $[26,46]$.

The vimentin-negative phenotype we found for the mammary stromal fibroblastoid cells is able to exclude a diagnosis of circulating fibrocytes and thus to characterise the cell population we studied as resident (constitutional). When TCs pattern was defined [31] cytoskeletal elements, such as thin and intermediate filaments were included; further studies documented the expression of vimentin in TCs [15]. This could equally indicate a progenitor or a fibroblastic phenotype, and does not bring so much in the cell type identification.

The human adipose-derived MSCs result from the stromal vascular fraction of adipose tissue but actually their specific surface markers, morphology and in vivo location are still debated [40]. These cells were found to represent a heterogeneous cell population, most of them constitutively expressing PDGFR and CD10 but variably expressing alpha-SMA, c-kit, Oct4 and CD68 [40]. The expression of CD10 in MSCs was reported either positive, or negative $[5,14,22,28,33]$. In the present study, the CD10 expression in the mammary samples was heterogeneous, positive or negative, as compared with the homogenous expression of CD34. This can relate to different stages of acquisition of the MSC phenotype in these cells. The assignment of CD10 only to a subset of MSCs was assessed by an in vitro study [2]. The CD10-positive phenotype was mostly encountered in the vicinity of the mammary vessels and excretory units. This is in accordance with the observations of Kim et al. [20], in human foetuses, that, similar to CD34, CD10 may be expressed not only in epithelial, but also in juxtaepithelial mesenchymal/ stromal tissues.

We found here multilayered sheaths of CD34-positive stromal cells wrapping around microvessels and excretory units, connected to the CD34-positive stromal networks. Guido Majno pointed in 1965 [18, $23]$ to cells of the perivascular niche with "protoplasmic expansions wrapped around the vessels". He termed these cells "veil cells" and these were further assumed to serve several main functions, fibrogenesis, phagocytosis, barrier function, and signal conduction [17, 45]. The veil cells of Majno [23] are fibroblastoid cells with a mesenchymal appearance which can be associated with MSCs potentialities [27]. This is consistent with continuously adding evidence which indicate that adult stem niches are, actually, perivascular $[7-10,48]$.

However, further exploration of MG TCS TEM is mandatory, as it could indicate, or not, ultrastructural peculiarities relating the mammary TCs to stem/ /progenitor cells. Of clinical interest remains the MG stromal stem niche contribution in various types of breast cancer; this could be a difficult task, as the contribution of bone marrow to stromal compartments is beyond any doubts and will thus blur a clear identification.

\section{CONCLUSIONS}

In conclusion, according to their morphology (e.g. the spindle shape, and the long, slender and moniliform prolongations linking the cells into stromal networks) the $\mathrm{CD} 34+/ \mathrm{CD} 10 \pm / \mathrm{c}$-kit-/vimentin-cells of the human mammary inter- and intralobular stroma could qualify as being TCs. However, their MSC potentiality is strongly suggested by their immune phenotypes.

\section{ACKNOWLEDGEMENTS}

This paper is supported (author \#1) by the Sectoral Operational Programme Human Resources Development (SOP HRD), financed from the European Social Fund and by the Romanian Government under the contract number POSDRU/159/1.5/S/132395/.

\section{REFERENCES}

1. Alison MR, Islam S (2009) Attributes of adult stem cells. J Pathol, 217: 144-160. doi: 10.1002/path.2498.

2. Battula VL, Treml S, Bareiss PM, Gieseke F, Roelofs H, de Zwart P, Muller I, Schewe B, Skutella T, Fibbe WE, Kanz L, Buhring HJ (2009) Isolation of functionally distinct mesenchymal stem cell subsets using antibodies against cd56, cd271, and mesenchymal stem cell antigen-1. Haematologica, 94: 173-184. doi: 10.3324/haematol.13740.

3. Bei Y, Zhou Q, Fu S, Lv D, Chen P, Chen Y, Wang F, Xiao J (2015) Cardiac telocytes and fibroblasts in primary culture: Different morphologies and immunophenotypes. PLoS One, 10:e0115991. doi: 10.1371/journal.pone.0115991.

4. Bucala R, Spiegel LA, Chesney J, Hogan M, Cerami A (1994) Circulating fibrocytes define a new leukocyte subpopulation that mediates tissue repair. Mol Med, 1: 71-81.

5. Buhring HJ, Battula VL, Treml S, Schewe B, Kanz L, Vogel W (2007) Novel markers for the prospective isolation of human msc. Ann N Y Acad Sci, 1106: 262-271. doi:10.1196/ annals.1392.000.

6. Catteau X, Simon P, Vanhaeverbeek M, Noel JC (2013) Variable stromal periductular expression of $\mathrm{cd} 34$ and 
smooth muscle actin (sma) in intraductal carcinoma of the breast. PLoS One, 8: e57773. doi: 10.1371/journal. pone. 0057773 .

7. Chen WC, Baily JE, Corselli M, Diaz ME, Sun B, Xiang G, Gray GA, Huard J, Peault B (2015) Human myocardial pericytes: Multipotent mesodermal precursors exhibiting cardiac specificity. Stem Cells, 33: 557-573. doi: 10.1002/ stem.1868.

8. Crisan M, Chen CW, Corselli M, Andriolo G, Lazzari L, Peault B (2009) Perivascular multipotent progenitor cells in human organs. Ann N Y Acad Sci, 1176: 118-123. doi: 10.1111/j.1749-6632.2009.04967.x.

9. Crisan M, Corselli M, Chen WC, Peault B (2012) Perivascular cells for regenerative medicine. J Cell Mol Med, 16: 2851-2860. doi: 10.1111/j.1582-4934.2012.01617.x.

10. Crisan M, Yap S, Casteilla L, Chen CW, Corselli M, Park TS, Andriolo G, Sun B, Zheng B, Zhang L, Norotte C, Teng PN, Traas J, Schugar R, Deasy BM, Badylak S, Buhring HJ, Giacobino JP, Lazzari L, Huard J, Peault B (2008) A perivascular origin for mesenchymal stem cells in multiple human organs. Cell Stem Cell, 3: 301-313. doi: 10.1016/j. stem.2008.07.003.

11. Diaz-Flores L, Gutierrez R, Garcia MP, Gonzalez M, Diaz-Flores L, Jr., Madrid JF (2015) Telocytes as a source of progenitor cells in regeneration and repair through granulation tissue. Curr Stem Cell Res Ther, Oct 1. [Epub ahead of print].

12. Diaz-Flores L, Gutierrez R, Garcia MP, Gonzalez M, Saez FJ, Aparicio F, Diaz-Flores L, Jr., Madrid JF (2015) Human resident cd34+ stromal cells/telocytes have progenitor capacity and are a source of alphasma + cells during repair. Histol Histopathol, 30: 615-627.

13. Diaz-Flores L, Gutierrez R, Garcia MP, Saez FJ, Diaz-Flores L, Jr., Valladares F, Madrid JF (2014) Cd34+ stromal cells/fibroblasts/fibrocytes/telocytes as a tissue reserve and a principal source of mesenchymal cells. Location, morphology, function and role in pathology. Histol Histopathol, 29: 831-870.

14. Farias VA, Linares-Fernandez JL, Penalver JL, Paya Colmenero JA, Ferron GO, Duran EL, Fernandez RM, Olivares EG, O’Valle F, Puertas A, Oliver FJ, Ruiz de Almodovar JM (2011) Human umbilical cord stromal stem cell express $\mathrm{cd} 10$ and exert contractile properties. Placenta, 32: 86-95. doi: 10.1016/j.placenta.2010.11.003.

15. Faussone Pellegrini MS, Popescu LM (2011) Telocytes. BioMol Concepts, 2: 481-489. doi:10.1515/BMC.2011.039.

16. Hall B, Andreeff M, Marini F (2007) The participation of mesenchymal stem cells in tumor stroma formation and their application as targeted-gene delivery vehicles. Handb Exp Pharmacol, 180: 263-283. doi: 10.1007/978-3-54068976-8_12

17. lijima T, Hasegawa K, Hirose H (1988) Wall structure of arteriovenous anastomoses in the rabbit ear. Combined light-, scanning- and transmission electron-microscopic studies. Cell Tissue Res, 252: 1-8.

18. Joris I, Majno G (1974) Cellular breakdown within the arterial wall. An ultrastructural study of the coronary artery in young and aging rats. Virchows Arch A Pathol Anat Histol, 364: 111-127.

19. Karnoub $A E$, Dash $A B$, Vo AP, Sullivan A, Brooks MW, Bell GW, Richardson AL, Polyak K, Tubo R, Weinberg RA (2007) Mesenchymal stem cells within tumour stroma promote breast cancer metastasis. Nature, 449: 557-563. doi:10.1038/nature06188.

20. Kim JH, Hwang SE, Yu HC, Hwang HP, Katori Y, Murakami G, Cho BH (2014) Distribution of cd10-positive epithelial and mesenchymal cells in human mid-term fetuses: a comparison with cd34 expression. Anat Cell Biol, 47: 28-39. doi: 10.5115/acb.2014.47.1.28.

21. Lv FJ, Tuan RS, Cheung KM, Leung VY (2014) The surface markers and identity of human mesenchymal stem cells. Stem Cells, 32: 1408-1419. doi: 10.1002/stem.1681.

22. Mafi P, Hindocha S, Mafi R, Griffin M, Khan WS (2011) Adult mesenchymal stem cells and cell surface characterization: a systematic review of the literature. Open Orthop J, 5: 253-260. doi: 10.2174/1874325001105010253.

23. Majno G (1965) Ultrastructure of the vascular membrane. Handbook Physiology, 3: 2293-2375.

24. Manea CM, Rusu MC, Constantin D, Manoiu VM, Moldovan L, Jianu AM (2014) Ultrastructural features of human adipose-derived multipotent mesenchymal stromal cells. Rom J Morphol Embryol, 55: 1363-1369.

25. Mou Y, Wang Y, Li J, Lu S, Duan C, Du Z, Yang G, Chen W, Zhao S, Zhou J, Wang C (2013) Immunohistochemical characterization and functional identification of mammary gland telocytes in the self-assembly of reconstituted breast cancer tissue in vitro. J Cell Mol Med, 17: 65-75. doi:10.1111/j.1582-4934.2012.01646.x.

26. Noort WA, Oerlemans MI, Rozemuller $H$, Feyen $D$, Jaksani S, Stecher D, Naaijkens B, Martens AC, Buhring HJ, Doevendans PA, Sluijter JP (2012) Human versus porcine mesenchymal stromal cells: Phenotype, differentiation potential, immunomodulation and cardiac improvement after transplantation. J Cell Mol Med, 16: 1827-1839. doi: 10.1111/j.1582-4934.2011.01455.x.

27. Pacilli $A$, Pasquinelli $G$ (2009) Vascular wall resident progenitor cells: a review. Exp Cell Res, 315: 901-914. doi: 10.1016/j.yexcr.2008.12.018.

28. Petre N, Vrapciu AD, Rusu MC (2015) Molecular anatomy of cd10. J Contemp Clin Pract, 1: 22-28. doi: 10.18683/ jсcp.2015.1005.

29. Popescu LM (2011) The tandem: telocytes — stem cells. Int J Biol Biomed Eng, 5: 83-92.

30. Popescu LM, Andrei F, Hinescu ME (2005) Snapshots of mammary gland interstitial cells: Methylene-blue vital staining and c-kit immunopositivity. J Cell Mol Med, 9: 476-477.

31. Popescu LM, Faussone-Pellegrini MS (2010) Telocytes a case of serendipity: The winding way from interstitial cells of cajal (icc), via interstitial cajal-like cells (iclc) to telocytes. J Cell Mol Med, 14: 729-740. doi: 10.1111/j.15824934.2010.01059.x.

32. Popescu LM, Manole CG, Gherghiceanu M, Ardelean A, Nicolescu MI, Hinescu ME, Kostin S (2010) Telocytes in human epicardium. J Cell Mol Med, 14: 2085-2093. doi: 10.1111/j.1582-4934.2010.01129.x.

33. Rasini V, Dominici M, Kluba T, Siegel G, Lusenti G, Northoff H, Horwitz EM, Schafer R (2013) Mesenchymal stromal/stem cells markers in the human bone marrow. Cytotherapy, 15: 292-306. doi:10.1016/j.jcyt.2012.11.009.

34. Rusu MC (2014) Letter to the editor. Skin telopodes. Rom J Morphol Embryol, 55: 723-724.

35. Rusu MC (2015) Why a stem cell diagnosis is quite difficult. Germs, 5: 38. doi: 10.11599/germs.2015.1068. 
36. Rusu MC, Didilescu AC, Stanescu R, Pop F, Manoiu VM, Jianu AM, Valcu M (2013) The mandibular ridge oral mucosa model of stromal influences on the endothelial tip cells: An immunohistochemical and tem study. Anat Rec (Hoboken), 296: 350-363. doi: 10.1002/ar.22630.

37. Rusu MC, Folescu R, Manoiu VS, Didilescu AC (2014) Suburothelial interstitial cells. Cells Tissues Organs, 199: 59-72. doi: 10.1159/000360816.

38. Rusu MC, Loreto C, Manoiu VS (2014) Network of telocytes in the temporomandibular joint disc of rats. Acta Histochem, 116: 663-668. doi: 10.1016/j.acthis.2013.12.005.

39. Rusu MC, Nicolescu MI, Jianu AM, Lighezan R, Manoiu VS, Paduraru D (2012) Esophageal telocytes and hybrid morphologies. Cell Biol Int, 36: 1079-1088. doi: 10.1042/ /CBI20120007.

40. Ryu YJ, Cho TJ, Lee DS, Choi JY, Cho J (2013) Phenotypic characterization and in vivo localization of human adipose-derived mesenchymal stem cells. Mol Cells, 35: 557-564. doi: 10.1007/s10059-013-0112-z.

41. Suciu L, Popescu LM, Gherghiceanu M, Regalia T, Nicolescu MI, Hinescu ME, Faussone-Pellegrini MS (2010) Telocytes in human term placenta: morphology and phenotype. Cells Tissues Organs, 192: 325-339. doi: 10.1159/000319467.

42. Sun X, Zheng M, Zhang M, Qian M, Zheng Y, Li M, Cretoiu D, Chen C, Chen L, Popescu LM, Wang X (2014) Differences in the expression of chromosome 1 genes between lung telocytes and other cells: Mesenchymal stem cells, fibroblasts, alveolar type ii cells, airway epithelial cells and lymphocytes. J Cell Mol Med, 18: 801-810. doi: 10.1111/ /jcmm.12302.

43. Vannucchi MG, Bani D, Faussone-Pellegrini MS (2015) Telocytes contribute as cell progenitors and differentiation inductors in tissue regeneration. Curr Stem Cell Res Ther, May 28. [Epub ahead of print].

44. Vrapciu AD, Rusu MC, Leonardi R, Corbu CG (2014) Stem potentialities of the human iris - an in situ immunohistochemical study. Acta Histochem, 116: 1509-1513. doi: 10.1016/j.acthis.2014.07.013.

45. Yamazaki K, Allen TD (1990) Ultrastructural morphometric study of efferent nerve terminals on murine bone marrow stromal cells, and the recognition of a novel anatomical unit: The "neuro-reticular complex". Am J Anat, 187: 261-276. doi: 10.1002/aja.1001870306.

46. Yang JF, Cao HC, Pan QL, Yu J, Li J, Li U (2015) Mesenchymal stem cells from the human umbilical cord ameliorate fulminant hepatic failure and increase survival in mice. Hepatobiliary Pancreat Dis Int, 14: 186-193.

47. Zhou J, Wang Y, Zhu P, Sun H, Mou Y, Duan C, Yao A, Lv S, Wang C (2014) Distribution and characteristics of telocytes as nurse cells in the architectural organization of engineered heart tissues. Sci China Life Sci, 57: 241-247. doi: 10.1007/s11427-013-4602-1.

48. Zimmerlin L, Donnenberg VS, Pfeifer ME, Meyer EM, Peault B, Rubin JP, Donnenberg AD (2010) Stromal vascular progenitors in adult human adipose tissue. Cytometry $A, 77$ : 22-30. doi: 10.1002/cyto.a.20813. 